\title{
An evaluation of casein hydrolyzate in combination with antibiotic for bacterial cure and subsequent increase in milk yield in dairy cows
}

\author{
Gabriel Leitner', Shamay Jacoby ${ }^{2}$, Nissim Silanikove ${ }^{2^{*}}$
}

\begin{abstract}
Background: A 3-yr study examined whether prepartum treatment with casein hydrolyzate in combination with antibiotic, as routinely used in Israel for dry cow therapy, improved bacterial cure and increased milk yield in subsequent lactations in comparison with treatment with antibiotic alone. The vast majority of bacterial isolates in samples collected prior to drying-off comprised coagulase-negative staphylococci, mostly as Staph. chromogenes.

Results: Bacterial cure associated with the combined treatment was $73.8 \%$ in cows, significantly higher than the $51.7 \%$ cure recorded when cows were treated only with antibiotic. During the study, the annual milk yield of noncasein hydrolyzate treated and treated control cows increased at $2 \%$ per year, which is consistent with the national annual increase attributed to genetic selection. In cows treated with casein hydrolyzate the increase was 9\% (above the 2\% expected) in the first lactation after the treatment, and 6.3\% (above the 4\% expected for 2 years) in the second lactation after treatment. These increases were significantly higher than those in the controls and those expected through genetic improvement.
\end{abstract}

Conclusions: Treatment with casein hydrolyzate at dry-off was shown to be a viable mean to eliminate existing environmental bacterial infection, and to improve milk yield in the next lactation.

\section{Background}

Active involution of the mammary gland is induced by milk stasis, which in turn triggers a negative feedback regulatory mechanism that leads to precipitous dry off of milk secretion and shrinkage of the secretory tissue (parenchyma) of the mammary gland $[1,2]$. Involution in cows $[3-6]$ and mice $[7,8]$ is associated with an inflammatory response that is characterized by activation of the glandular immune system, accelerated apoptosis of epithelial cells, and tissue remodeling $[1,2,9]$. The process of active involution that follows milk stasis in goats [10] and cows [11] can be triggered by the induction of intensive plasmin activity in milk; this, in turn liberates casein-derived active peptides [12]. Infusion of casein hydrolyzate $(\mathrm{CNH})$, which contains active casein-derived peptides, dramatically accelerated the involution, which was completed within 3 days in goats and cows, compared with 3-4 weeks without such

\footnotetext{
* Correspondence: nsilanik@agri.huji.ac.il

${ }^{2}$ Biology of Lactation Laboratory, Institute of Animal Science, the Volcani

Center, P.O.B. 6, Bet Dagan 50250, Israel

Full list of author information is available at the end of the article
}

treatment, and resulted in a marked reduction in milk yield (MY) even after the first day of treatment $[10,11,13]$. These responses were manifested in the mammary secretion within $8 \mathrm{~h}$ after the first application, which relates to the forceful activation of the innate immune system and the drastic reduction in nutrient availability (mainly lactose) for bacterial growth [13].

These properties of $\mathrm{CNH}$ were exploited successfully to eliminate quarter-udder infection by drying-off the infected glands during lactation, which resumed normal milk secretion in the subsequent lactation [14]. Moreover, it was found that infusion of $\mathrm{CNH}$ induced marked bactericidal and bacteriostatic responses against udder pathogens, such as Escherichia coli and Staphylococcus aureus, in the involuted gland secretion as tested in vitro [13].

Casein hydrolyzate may be used as a tool to reduce the discomfort associated with drying-off of modern high-yielding dairy cows, by preventing the enormous udder engorgement that typically develops with this management process [15]. 
It has been well established that the beginning of the dry period in dairy cows is associated with an increased risk of acquiring intramammary infection (IMI)[16]. This increased risk is closely related to MY at dryingoff, and may be related to increased incidence of milk leakage from the udder [17] and the slow activation of the innate immune system [13]. Each $5 \mathrm{~kg} / \mathrm{d}$ increase in MY above $12.5 \mathrm{~kg} / \mathrm{d}$ at dry-off increase the probability of acquiring new IMI with environmental bacteria by $77 \%$ [17]. Thus, in Israel and in other countries, most cows are at high risk of acquiring IMI at drying-off, because they are still producing milk at over $20 \mathrm{~L} / \mathrm{d}$.

It was hypothesized that acceleration of the involution process might increase bacterial cure [18-20] and result in increased MY in the subsequent lactation [1]. The aims of the present study were to determine whether intramammary $\mathrm{CNH}$ treatment at drying-off would result in improved bacterial cure of existing IMI, and increased MY in the subsequent lactation. Since it was the first time that the efficacy of $\mathrm{CNH}$ as dry cow treatment (DCT) was tested and because the study was performed in a commercial herd, a combination of $\mathrm{CNH}$ with an antibiotic treatment was used instead of $\mathrm{CNH}$ alone. Due to management limitations, $\mathrm{CNH}$ was tested only during one year of the 3-year study. For testing the efficiency of the $\mathrm{CNH}$ treatment for curing/preventing bacterial infection the year prior to the $\mathrm{CNH}$ usage and the year after served as control. To overcome the effects associated with genetic improvement, the MY of heifers, which entered the herd throughout the 3-year study was analyzed and served as a covariate.

\section{Methods \\ Materials}

A commercial nafcillin/procaine penicillin G/dihydrostreptomycin preparation, Nafpenzal DC (Intervet, the Netherlands), which is a medication for DCT, was used according to the manufacturer's instructions. A pre-commercial prototype of the $\mathrm{CNH}$ was prepared under Good Laboratory Practice conditions [15] and was used in combination with Nafpenzal DC for DCT. The CNH solution was a sterile pyrogen-free liquid preparation that was stored in sterile vials [15]. Each infusion into a quarter contained $10 \mathrm{~mL}$ of $\mathrm{CNH}$, with a peptide concentration of $7.2 \mathrm{mg} / \mathrm{mL}$ followed by a Nafpenzal DC tube.

\section{Study design}

All protocols were approved by the Institutional Animal Care Committee of the Agricultural Research Organization, which is the legitimate body for such authorizations in Israel.

The study extended over 3 years and is summarized in Table 1; it covered Israeli Holstein cows (pluriparous; second lactation and above) and heifers (first lactation) of the commercial-experimental herd of the Agricultural Research Organization, Bet Dagan, Israel, which holds 250 animals. Cows and heifers were held in high-roof barns suitable for sub-tropical conditions, and were fed a typical Israeli TMR comprising $65 \%$ concentrates and $17 \%$ protein. The food and water managers were located in the shed. During the summer months (June to September) the cows are routinely cooled by fans and sprinklers. Two dry-off treatments were compared: Nafpenzal DC, and Nafpenzal DC combined with $\mathrm{CNH}$ infused to each quarter in the treated cows. The cows were treated in accordance with their dry-off schedules. Cows included in "Period 1" (August 2004 to August 2005) were dry-off treated with antibiotic. In the following season, from September 2005 to June 2006 (Period 2 ), the vast majority of the cows in the herd were dryoff treated with a combination of antibiotic and $\mathrm{CNH}$, and a group of 17 cows, that served as control cows, were treated only with antibiotic for DCT. In the third season of observation, from July 2006 to April 2007 (Period 3), all the cows were dry-off treated with antibiotic. All the heifers that joined the herd during Periods 1 to 3 were included to enable comparison of the evolution of their MY with that of the experimental cows. Heifers were not treated for DCT. The number of animals recorded in each season is indicated in Table 1 . Because of the natural dynamics of the herd population, 41 cows were observed during all 3 Periods, 101 cows in 2 Periods and 162 cows in one Period; a total of 481 cows (Table 1).

Table 1 Experimental structure: animals (number and types), treatments, and Periods

\begin{tabular}{|c|c|c|c|c|}
\hline Period & Time & Animals & Number & Treatment \\
\hline \multirow[t]{2}{*}{1} & Aug. 04 - Aug. 05 & heifers & 74 & None \\
\hline & & cows & 111 & Naf. DC \\
\hline \multirow[t]{3}{*}{2} & Sep. 05 - June 06 & heifers & 56 & None \\
\hline & & cows & 92 & Naf. DC + CNH \\
\hline & & control cows & 17 & Naf. DC \\
\hline \multirow[t]{2}{*}{3} & July 06 - April 07 & heifers & 48 & None \\
\hline & & cows & 83 & Naf. DC \\
\hline
\end{tabular}


The average MY in this farm at 2005 was $11,135 \mathrm{~L}$ during 305 days of lactation and the average bulk tank somatic cell count (SCC) was 236,000 . Milk yield and SCC were retrieved from the routine monthly record of this information for each Holstein cow in Israel by the Israeli Cattle Breeders' Association. All animals were sampled by quarter, for SCC and bacterial udder infection, as follows: 3 times at weekly intervals during the last month before drying-off; at the time of parturition (days 0 to 3); and monthly for up to 100 (range 95 to 105) days during the subsequent lactation. Thus, each cow was sampled 4 times during this period. A cow was considered infected when at least two of the milk samples were positive with the same bacterium accompanied by increased SCC.

\section{Bacteriological analysis}

Duplicate quarter foremilk samples were taken aseptically and submitted to the laboratory within one h. Bacteriological analysis was performed according to accepted standards of microbiological procedures as described by the National Mastitis Council [21]. All samples were taken during milking. Udder quarters were cleaned and disinfected prior to sampling with a non-woven disposable commercial wipe that was moistened with chlorhexidine, cetrimide and ethanol. The three first squirts of milk were discarded and approximately 3-5 ml of milk were taken in sterile tubes. From every milk sample, $0.01 \mathrm{~mL}$ was spread onto blood-agar plates (Bacto-Agar; Difco Laboratory Becton, Dickinson and Company, France) containing 5\% of washed red sheep blood cells and on MacConkey plates. All plates were incubated at $37^{\circ} \mathrm{C}$ and examined for growth after 18 and $42 \mathrm{~h}$. If there was no agreement between duplicates the quarters were sampled again. Colonies suspected to be staphylococci were tested for coagulase (tube test, Anilab, Rehovot, Israel). Species identification was carried out with the API STAPH-IDENT, 32 Staph kit or rapid ID 32 STREP (bioMerieux S.A., 69280 Marcy l'Etoile, France). When micrococci-like bacteria in given sample matched the reference kit specie by > $90 \%$, the specie was regarded as specific.

Bacterial cure was defined as the absence of the bacteria identified in the same quarter in the month preceding drying-off from the milk sampled during the first 100 days of a new lactation (i.e., in at least 4 postpartum milk sampling). New infection was defined as the appearance of infection that was absent from samples taken before drying-off in the previous lactation in a given quarter at the start of the new lactation. In order to be defined as new infection, the infection could be identified in milk sampled during the first $3 \mathrm{~d}$ postpartum, or in the first month of postpartum samples; it should have persisted for at least 2 additional samplings, i.e., during the first 100 days of lactation. Clinical infections were defined by the herd veterinarian by forstripping milk of suspicious cows. The SCC in milk was determined in the central laboratory of the Israeli Dairy Cow Breeders' Association, according to established standard procedures [22].

\section{Statistical Analysis}

All the statistical analysis procedures were carried out with the JMP software [23]. All the main measures (cure rate, $\mathrm{CC}$ and milk yield) were analyzed according to the following model:

$$
\mathrm{Y}_{\mathrm{ijk}}=\mu+\alpha_{\mathrm{i}}+\beta_{\mathrm{j}}+\alpha \beta_{\mathrm{ij}}+\mathrm{K}_{\mathrm{l}}+\alpha \mathrm{K}_{\mathrm{il}}+\mathrm{e}_{\mathrm{ijkl}}
$$

where $\mu=$ Mean of all data, $\alpha_{i}=$ effect of Period, i ( $i=$ $1,2$ or 3$) ; \beta j=$ effect of cow category $(j=1,2$ or 3 for heifer, experimental, and control cow, respectively); $\alpha \beta_{\mathrm{ij}}$ $=$ the cow category $\times$ Period interaction; $K_{1}=$ effect of lactation number of cows $(1=2,3$, or $>4) ; \alpha K_{i l}$ - interaction of period and cows lactation number and $\mathrm{e}_{\mathrm{ijkl}}=$ residual variance between measurements (random error).

Because the effects of $K_{l}$ and $\alpha K_{i l}$ were not significant, similar statistical results were obtained when treatments were also analyzed by the Pearson's chi-square $\left(x^{2}\right)$ test: Nafpenzal DC and Nafpenzal DC combined with $\mathrm{CNH}$ were compared by the $\chi^{2}$ testfor their effects on: quarter's bacterial cure and acquisition of new infections in experimental cows from Periods 2 and 3. For simplicity, only the $x^{2}$ analysis was presented in Table 2 .

Milk yield comparisons were based on the monthly MY during the first 5 months of lactation according to the above model.

The above statistical model with the inclusion of the effect of SCC (categories of < 50,000; 50,000 to 700,000; and $>700,000)$ and the interaction of SCC with period effect was used to analyze the effect of SCC on milk yield. Alternatively, for all three periods, the effect of the same SCC categories on milk yield was analyzed by the $X^{2}$ test. The statistical analysis by both methods, yielded similar predictions, and for simplicity the $\chi^{2}$ test results are presented in Table 3.

\section{Results}

\section{Bacteriology}

Of the 92 cows (368 glands) that gave birth during Period 2 and had been treated with Nafpenzal DC in combination with $\mathrm{CNH}$ in the dry period at the end of Period $1,88.6 \%$ of the glands (326/368) were uninfected, and infection was detected in $11.4 \%(42 / 368)$ at dry-off (Table 2). Of the 326 uninfected glands, 312 (95.7\%) remained uninfected through $100 \mathrm{~d}$ of the lactation (range 95 to $105 \mathrm{~d}$ ), and 14 (4.3\%) exhibited new 
Table 2 Bacterial status (infected, noninfected, subclinical, clinical and cured) in Period 2 (experimental, following Nafpenzal DC + CNH at DCT) and Period 3 (control, following Nafpenzal DC)

\begin{tabular}{lllll}
\hline & & Period 2 (experimental period) & Period 3 (control period) & $P\left[\boldsymbol{X}^{2}\right]$ \\
\hline Before drying-off & Cow/glands & $92 / 368$ & $83 / 332$ & NS \\
& Uninfected & $326 / 368(88.6)$ & $274 / 332(82.5)$ & NS \\
Infected & $42 / 368(11.4)$ & $58 / 332(17.5)$ & NS \\
Postpartum & Uninfected & $259 / 274(94.5)$ & NS \\
& Subclinical & NS \\
& Clinical $^{3}$ & $112 / 326(95.7)$ & $15 / 274(5.5)$ & NS \\
& Cured $^{4}$ & $28 / 326(8.6)$ & $20 / 274(7.3)$ & 0.025 \\
& Not Cured $^{5}$ & $31 / 42(73.8)$ & $30 / 58(51.7)$ & 0.025 \\
\hline
\end{tabular}

\footnotetext{
${ }^{1}$ Uninfected quarter before drying-off and uninfected at parturition.

${ }^{2}$ New Infection, subclinical - Infection was detected during parturition and in the first 100 days in the new lactation: The same udders were uninfected before drying-off.

${ }^{3}$ New Infection, clinical - Infection was detected during the first month after parturition and remained for the first 100 days in the new lactation: The same udders were uninfected before drying-off.

${ }^{4}$ Cure - Bacteria detected in the month preceding dry-off was not detected in the same udder during the first 100 days of lactation.

${ }^{5}$ Not Cured - The reciprocal of cured: Bacteria detected in given udders in the month preceding dry-off was also detected in the same udder during the first 100 days of the subsequent lactation.
}

bacterial infection immediately postpartum (day 0 to 3 ), and this persisted in sub-clinical forms through $100 \mathrm{~d}$ of the lactation. In $28(8.6 \%)$ out of 326 glands newly acquired bacterial clinical infection was detected during the first month. Bacterial cure of cows entering the dry period infected was detected in 31 out of 42 glands $(73.8 \%)$, and 11 out of $42(26.2 \%)$ glands remained infected with the same bacteria (Table 2).

For comparison among the 83 cows (332 quarters) that gave birth during Period 3 and had been treated with Nafpenzal DC during the preceding dry period, $82.5 \%$ of the glands were bacteria free and $17.5 \%$ were infected at dry-off (Table 2). Of the 274 uninfected glands, 259, i.e., $94.5 \%$, remained uninfected through $100 \mathrm{~d}$ of the lactation, and 15, i.e., 5.5\%, exhibited new bacterial infection immediately postpartum (days 0 to 3 ), and this infection persisted sub-clinically through $100 \mathrm{~d}$ of the lactation. In $20(7.3 \%)$ of the 274 glands, newly acquired clinical bacterial infection was detected during the first month of lactation (Table 2). Bacterial cure of cows that entered the dry period infected was observed in 30 out of the 58 glands (51.7\%), and 28 (48.3\%) glands remained infected with the same bacteria (Table 2).

The vast majority of bacterial isolates (92\%) in the month preceding the dry period were identified as

Table 3 Distribution of SCC (cells/ml) in Periods 1, 2 and 3

\begin{tabular}{|c|c|c|c|c|}
\hline \multicolumn{2}{|c|}{ SCC (category) } & \multicolumn{2}{|c|}{ Period } & \multirow[t]{2}{*}{$P\left[x^{2}\right]$} \\
\hline & 1 & 2 & 3 & \\
\hline$<50,000$ & 54.9 & 65.7 & 66.3 & NS \\
\hline $50-700,000$ & 24.4 & 15.8 & 15.7 & NS \\
\hline$>700,000$ & 9.9 & 9.2 & 10.1 & NS \\
\hline Clinical infection & 10.8 & 9.3 & 7.8 & NS \\
\hline
\end{tabular}

coagulase negative staphylococci (CNS), mostly Staph. chromogenes (85\%). Thus, 'bacterial cure' by DCT in the present study refers almost exclusively to cure from CNS infection. New infections that were identified on day 0 were not associated with clinical mastitis and were caused exclusively by CNS (7\%); these infections developed into chronic infections that persisted for at least $100 \mathrm{~d}$. The vast majority (93\%) of bacterial infections detected during the first month caused clinical mastitis; E. coli and Streptococcus dysgalactiae were identified as the causative agents. Based on their absence in the next samplings, it can be concluded that these infections were cured either spontaneously (mostly E. coli) or by treatment with antibiotic. In few cases (1 to 2 per lactation), the infection did not cured and was a ground for culling. Thus, routine antibiotic treatment with Nafpenzal DC at dry-off provided only 51.7\% cure whereas this treatment in combination with $\mathrm{CNH}$ significantly increased the cure to $73.8 \%$ (Table $2 P=$ $0.025)$. No differences were found between the treatments in new infection rates, either with CNS during the dry period or with E. coli and Streptococcus dysgalactiae during the lactation.

\section{Somatic Cells}

The proportion of udders with SCC less than 50,000 cells $/ \mathrm{mL}$ increased from $54.9 \%$ in Period 1 to $65.7 \%$ in Period 2 and to $66.3 \%$ in Period 3, whereas the proportions with SCC in the range of 50,000 to 700,000 were 24.4, 15.8, and $15.7 \%$ in Periods 1, 2, and 3, respectively. Although the proportion of cows with lower SCC increased in Periods 2 and 3, the differences were not significant (Table 3). The numerical changes in the rates of SCC > 700,000 and of clinical infections in the 3 Periods were not significant. 


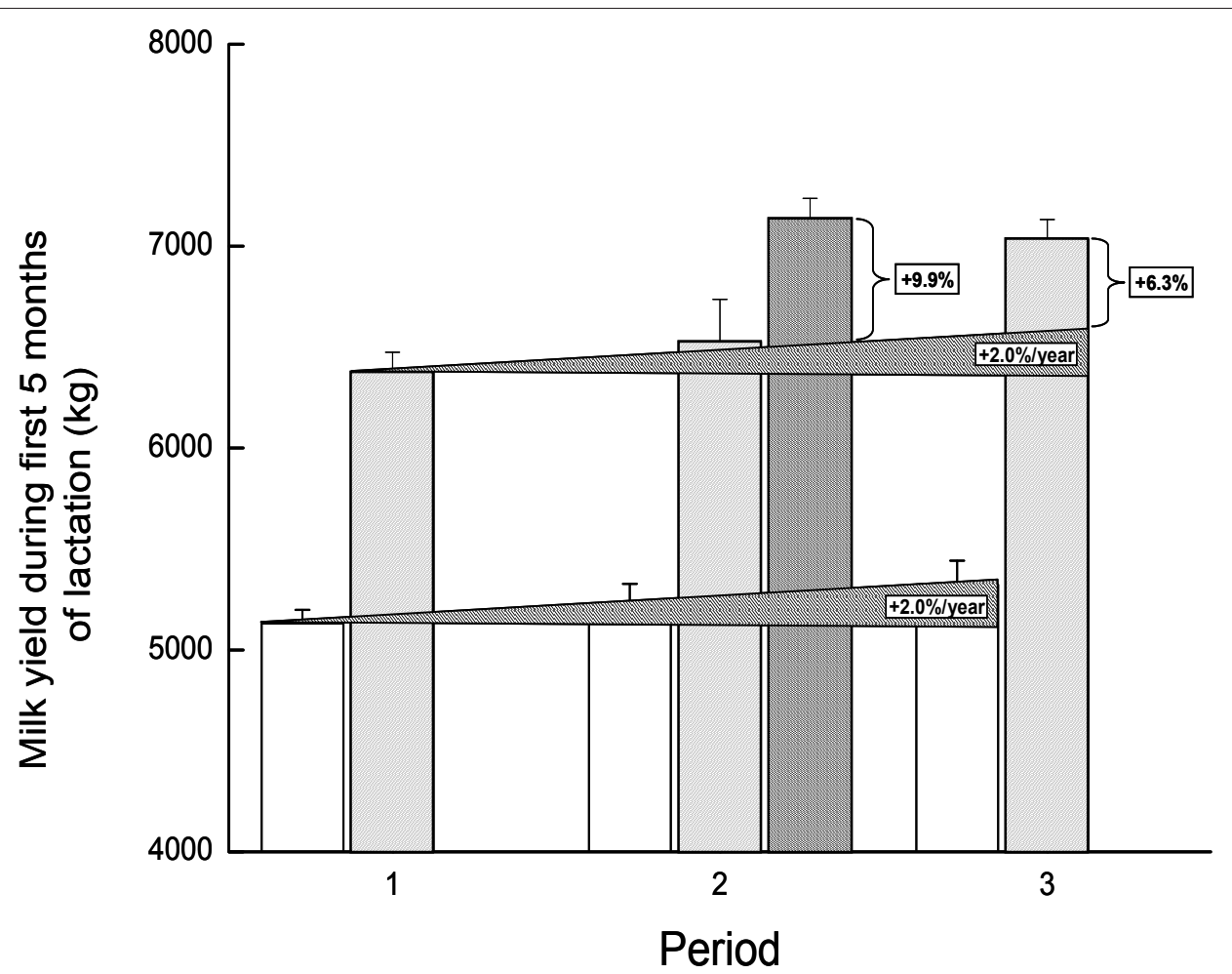

Figure 1 Milk yield during first 5 months of lactation (kg).

\section{Milk Yield}

The MY of the heifers increased by $2 \%$ (about $220 \mathrm{~L}$ per cow) each year, from 5,130 L over 5 months in Period 1 to 5,323 L over 5 months in Period 3 (Figure 1). A similar increase of about $2 \%$ from Period 1 to Period 2 (6,374 to 6,526 L over 5 months) was recorded in the 17 control cows. The increase in MY among the heifers and the pluriparous control cows was not significant. In contrast, a significant $(P<0.0001)$ increase in MY from Period 1 to Period 2 by about $760 \mathrm{~L}$ per cow (i.e., from 6,374 in the first 5 month of period 1 to $7,132 \mathrm{~L}$ per cow in the first 5 month of period 2 following $\mathrm{CNH}$ treatment at dry-off of period 1) over 5 months was recorded in the pluriparous cows. Thus, the yield increase of the tested cows was $9.9 \%$ higher than the expected $2 \%$ per year $(P<0.001)$. These significant difference $(P<0.0001)$ were maintained in Period 3 , in which the increase in MY was $10.4 \%$ higher than in Period 1 (from 6,374 in the first 5 month of period 1 to 7,033 $\mathrm{L}$ in the first 5 month of period 3 following $\mathrm{CNH}$ treatment at dry-off of period 1), (6.3\% higher the $4 \%$ expected; $P<0.001$ ). These differences remained highly significant, even after accounting for the natural annual $2 \%$ increase in MY in the whole herd, as recorded in the control groups of heifers and cows (Figure 1).

Analysis of the effect of SCC on MY (Table 3), indicates that the non-significant reduction in SCC level in the experimental cows cannot explain the increase in MY in those cows.

\section{Discussion}

\section{Study Design}

The present study was a feasibility study intended to analyze the effect of $\mathrm{CNH}$ treatment in a commercial herd with minimal interference to its day-to-day routine, which explains the somewhat unusual experimental design. The potential pitfalls in such a design are that it is subjected to confounding results because of year-to-year variations of food composition, environmental conditions, management etc. Thus, a special precautions in the experimental design included the use of heifers as control for changes relating to genetic improvement of MY, to account for such interferences, and therefore the results reflect the studied effects of the $\mathrm{CNH}$ dry-off treatment.

\section{CNH Treatment Improved Bacterial Cure of CNS}

The present results show that treatment with antibiotic plus CNH DCT was effective in curing CNS IMI. This is important because: (i) it provides a means for preventing deterioration in milk quality and associated economic losses; and (ii) it provides a potential means to prevent the hazard associated with routine use of high doses of antibiotic, with blanket DCT procedures, that have become the accepted tool to control IMI in Israel 
and other countries. Although in the present study, treatment with $\mathrm{CNH}$ was accompany by antibiotics, the significant improvement in bacterial cure in comparison to treatment with antibiotic alone under farming conditions provided evidence that intra-mammary $\mathrm{CNH}$ treatment has the potential for being developed into an effective non-antibiotic, non-hormonal DCT for bacterial cure. Nevertheless, in order to advance this potential, the benefit in using $\mathrm{CNH}$ over conventional antibiotic DCT should be demonstrated in a controlled study at dry-off.

A decade ago, CNS were often regarded as pathogens of minor importance [24,25], especially in comparison with Staph. aureus, streptococci, and coliforms, which may cause severe mastitis. Nevertheless, in many countries, including Israel, CNS are the predominant pathogens associated with mastitis [24-27]. Mastitis caused by CNS usually remains subclinical or mildly clinical $[28,29]$, but it may decrease milk production $[22,30]$. Leitner et al. $[22,31,32]$ have shown that losses in curd yield caused by the use of CNS-infected milk are several times as great as the milk losses, because of simultaneous deterioration in milk quality. Thus, if milk is being allocated for cheese production, the economic burden imposed on dairies by loss in curd yield is greater than that imposed on farmers by loss of MY [22].

Although we cannot exclude the possibility of reinfection with the same species following its elimination, we assume that in the present study the CNS infections recorded immediately postpartum persisted in the udder through the entire lactation. This conclusion is consistent with evidence that CNS are capable of persisting in the udder for months or even throughout the lactation $[28,29,33]$.

Some studies have found rather high spontaneous CNS cure rates of about 60 to $70 \%$ during the dry period [34], whereas others found markedly lower rates, ranging from 15.5 to $44 \%$ [16,35]. In a broad survey of heifers in the USA and Canada it was found that quarters that were infected prepartum, mostly with CNS, and were treated with antibiotics had a 59.5\% cure rate, compared with a spontaneous cure rate of $31.7 \%$ [36]. A study on heifers in 2 research dairy herds yielded a very similar CNS cure rate [37]. The somewhat lower cure rate obtained with antibiotic DCT in the present study may be related to the fact that our subjects were cows, or to the stricter criteria we applied to define a cure, compared with that used in standard definitions, i.e., absence of infection during the first month of lactation. Burriel [38] found that CNS can adhere to and produce slime in various tissues, including epithelial cells of the mammary gland. Thus, the absence of CNS from a culture of a given sample does not necessary indicate their absence from the sampled tissue [39]. This hypothesis is supported by the findings of a large study in Norway that covered a total of 684 cows from 288 different herds in 3 Norwegian regions, DCT of infected quarters led to a 5.2:1 greater probability of the quarters being healthy within $30 \pm 17$ days into the next lactation than that in control (non-treated) groups. Nevertheless, the overall frequency of CNS in the sampled quarters of cured cows at the end of lactation was no different from that among of the control cows [40]. The above findings justify our more strict criteria for defining a cure, and also emphasize that the success of the present $\mathrm{CNH}$ treatment in significantly improving the CNS cure rate was genuine.

In the present study none of the cows were infected with Staph. aureus, and the numbers of cows infected with coliforms and streptococci were too low to assess the efficacy of the $\mathrm{CNH}$ treatment in curing or preventing such infections. However, in a previous study, $\mathrm{CNH}$ treatment of single quarters during lactation has been shown to be effective in curing chronic and subclinical mastitis associated with these bacteria [14]. Thus, it is worth further investigating the potential benefit of applying this method as a DCT to cure and reduce the SCC counts in herds having higher than the typical proportion of coliforms, streptococci and Staph. aureus IMI at dry-off in Israel.

\section{DCT with CNH Increased Milk Yield}

The progressive increase in MY at 2\% per year in heifers or in the control cows is typical of the yearly improvement in MY attributed to genetic improvement in Israeli dairy herds [41]. Thus, the increase in MY that was recorded in the experimental cows considerably exceeded any plausible trend. No such response was recorded in cows treated with antibiotic only, i.e., the 17 control cows and those observed in Period 2 that had joined the trial as heifers in Period 1 and 2, therefore this MY enhancement can be related exclusively to the effect of treating the cows with $\mathrm{CNH}$.

Two hypotheses may account for this increase. First, it may relate to the higher cure rate and the reduction in the population of SCC that typically is negatively related to MY [20]. However, analysis of MY as related to SCC distribution indicates that in the present case the effect of $\mathrm{CNH}$ treatment on lowering of SCC was far from significant, probably because the infection rate and, therefore, the SCC, were initially low and also because treatment did not affect new IMI in the subsequent lactation. Thus, in herds with poorer initial conditions, this effect would be expected to be more noticeable. The second hypothesis relates to the fact that treatment with $\mathrm{CNH}$ accelerated gland involution $[11,13]$. Thus, this procedure probably increased epithelial cell apoptosis at 
the start of the dry period. As the gland parenchyma rebuilt itself during the period preceding the subsequent parturition, it may be expected that it would be composed of larger proportion of newly synthesized epithelial cells, which would be expected to enhance the gland milk production capacity [1]. Our results suggest that this effect persisted through two subsequent lactations.

\section{Conclusion}

This study provided evidence that intra-mammary $\mathrm{CNH}$ treatment has the potential for development as an effective non-antibiotic, non-hormonal DCT for bacterial cure and for enhanced MY in the subsequent lactation. Further research along this line is therefore warranted, particularly under the following conditions: (i) In herds presenting broader bacterial infection status and higher bulk tank SCC; (iii) In combination with teat sealers, thus contributing also to prevention of new IMI around parturition (iv) In exploiting the accelerating effect of $\mathrm{CNH}$ treatment on the involution rate, to shorten the dry period without impairing the next-lactation MY, or even improving it and (v) Because it is a natural product, $\mathrm{CNH}$ treatment has the potential to prevent the transmission of methicillin resistant genes and those resistant to other antibiotics.

\section{Author details}

'National Mastitis Reference Center, Kimron Veterinary Institute, P.O.B. 12, Bet Dagan 50250, Israel. ${ }^{2}$ Biology of Lactation Laboratory, Institute of Animal Science, the Volcani Center, P.O.B. 6, Bet Dagan 50250, Israel.

\section{Authors' contributions}

$G L$ and NS were responsible for performing the experiments and for the analysis of the data, interpretation of the results and the writing of the manuscript. NS prepared the CNH solution and wrote the first draft of the paper. $\mathrm{SJ}$ is the farm manager and participated in performing the experimental treatments. All authors read and approved the final manuscript.

Received: 24 December 2009 Accepted: 7 January 2011

Published: 7 January 2011

\section{References}

1. Capuco AV, Akers RM: Mammary involution in dairy animals. Journal of Mammary Gland Biology and Neoplasia 1999, 4:137-144.

2. Wilde $\mathrm{CJ}$, Knight $\mathrm{CH}$, Flint DJ: Control of milk secretion and apopotosis during mammary involution. Journal of Mammary Gland Biology and Neoplasia 1999, 4:129-136.

3. Holst $B D$, Hurley WL, Nelson DR: Involution of the bovine mammary gland: Histological and ultrastructural changes. Journal of Dairy Science 1987, 70:935-944.

4. Hurley WL: Mammary glands function during involution. Journal of Dairy Science 1989, 72:1637-1646.

5. Sordillo LM, Nickerson SC: Morphologic changes in the bovine mammary gland - histological and ultrastructural changes. American Journal of Veterinary Research 1988, 49:1112-1120.

6. Leitner G, Anug AM, Merin U, Silanikove N: Pregnancy obstructs involution stage 2 of the bovine mammary gland: General biological implications. Israel Journal of Veterinary Medicine 2007, 62:91-97.

7. Clarkson RWE, Wayland MI, Lee J, Freeman T, Watson CJ: Gene expression profiling of mammary gland development reveals putative roles for death receptors and immune mediators in post-lactational regression. Breast Cancer Research 2004, 6:R92-R109.

8. Stein T, Morris JS, Davies CR, Weber-Hall SJ, Duffy MA, Heath VJ, Bell AK, Ferrier RK, Sandilands GP, Gusterson BA: Involution of the mouse mammary gland is associated with an immune cascade and an acutephase response, involving LBP, CD14 and STAT3. Breast Cancer Research 2004, 6:R75-R91.

9. Singh K, Davis SR, Dobson JM, Molenaar AJ, Wheeler TT, Prosser CG, Farr VC, Oden K, Swanson KM, Phyn CVC, Hyndman DL, Wilson T, Henderson HV, Stelwagen K: cDNA microarray analysis reveals that antioxidant and immune genes are upregulated during involution of the bovine mammary gland. Journal of Dairy Science 2008, 91:2236-2246.

10. Shamay A, Shapiro F, Mabjeesh SJ, Silanikove N: Casein-derived phosphopeptides disrupt tight junction integrity, and precipitously dry up milk secretion in goats. Life Sciences 2002, 70:2707-2719.

11. Shamay A, Shapiro F, Leitner G, Silanikove N: Infusions of casein hydrolyzates into the mammary gland disrupt tight junction integrity and induce involution in cows. Journal of Dairy Science 2003, 86:1250-1258.

12. Silanikove N, Merin U, Leitner G: Physiological role of indigenous milk enzymes: an overview of an evolving picture. International Dairy Journal 2006, 16:533-545.

13. Silanikove N, Shapiro F, Shamay A, Leitner G: Role of xanthine oxidase, lactoperoxidase, and NO in the innate immune system of mammary secretion during active involution in dairy cows: manipulation with casein hydrolyzates. Free Radical Biology Medicine 2005, 38:1139-1151.

14. Silanikove N, Iscovich J, Leitner G: Therapeutic treatment with casein hydrolyzate eradicate effectively bacterial infection in treated mammary quarters in cows.Edited by: Hogeveen H. Mastitis in Dairy Production: Current Knowledge and Future Solutions, Wageningen Academic Publishers, Wageningen, the Netherlands; 2005:327-332.

15. Leitner G, Shamay J, Maltz E, Silanikove N: Casein hydrolyzate intramammary treatment improves the comfort behavior of cows induced into dry-off. Livestock Science 2007, 110:292-297.

16. Rainard P, Poutrel B: Dynamics of non-clinical bovine intra-mammary infections with major and minor pathogens. American Journal of Veterinary Research 1982, 43:2143-2146.

17. Rajala-Schultz PJ, Hogan JS, Smith KL: Association between milk yield at dry-off and probability of intramammary infections at calving. Journal of Dairy Science 2005, 88:577-579.

18. Oliver SP, Smith KL: Bovine mammary involution following intramammary infusion on colchicine and endotoxin at drying off. Journal of Dairy Science 1982, 65:801-813.

19. Oliver SP, Smith KL: Nonantibiotic approach in control of bovine mastitis during dry period. Journal of Dairy Science 1982, 65:2119-2124.

20. Oliver SP, Sordillo LM: Approaches to the manipulation of mammary involution. Journal of Dairy Science 1989, 72:1647-1664.

21. Oliver SP, Gonzalez RN, Hogan JS, Jayarao BM, Owens WE: Microbiological Procedures for the Diagnosis of Bovine Udder Infection and Determination of Milk Quality. The National Mastitis Council, Inc., Verona, WI, USA; 42004

22. Leitner G, Krifucks O, Merin U, Lavi Y, Silanikove N: Interactions between bacteria type, proteolysis of casein and physico-chemical properties of bovine milk. International Dairy Journal 2006, 16:648-654.

23. SAS Institute: JMP User's guide. SAS Institute, Cary, NC, USA; 2000.

24. Makovec JA, Ruegg PL: Results of milk samples submitted for microbiological examination in Wisconsin from 1994 to 2001. Journal of Dairy Science 2003, 86:3466-3472.

25. Pyörälä S, Taponen S: Coagulase-negative staphylococci-Emerging mastitis pathogens. Veterinary Microbiology 2009, 134:3-8.

26. Chaffer M, Leitner G, Winkler M, Glickman A, Krifucks O, Ezra E, Saran A: Coagulase-negative staphylococci and mammary gland infections in cows. Journal of Veterinary Medicine B 1999, 46:707-712.

27. Waage S, Mork T, Roros A, Aasland D, Hunshamar A, Odegaard SA: Bacteria associated with clinical mastitis in dairy heifers. Journal of Dairy Science 1999, 82:712-719.

28. Taponen S, Simojokia H, Haveria M, Larsen HD, Pyörälä S: Clinical characteristics and persistence of bovine mastitis caused by different species of coagulase-negative staphylococci identified with API or AFLP. Veterinary Microbiology 2006, 115:199-207. 
29. Taponen S, Koort J, Björkroth J, Saloniemi H, Pyörälä S: Bovine intramammary infections caused by coagulase-negative staphylococci may persist throughout lactation according to amplified fragment length polymorphism-based analysis. Journal of Dairy Science 2007, 90:3301-3307.

30. Gröhn YT, Wilson DJ, Gonzalez RN, Hertl JA, Schulte H, Bennett G, Schukken YH: Effect of pathogen-specific clinical mastitis on milk yield in dairy cows. Journal of Dairy Science 2004, 87:3358-3374.

31. Leitner G, Chaffer M, Shamay A, Shapiro F, Merin U, Ezra E, Saran A, Silanikove N: Changes in milk composition as affected by subclinical mastitis in sheep. Journal of Dairy Science 2004, 87:46-52.

32. Leitner $\mathrm{G}$, Merin $\mathrm{U}$, Silanikove $\mathrm{N}$ : Changes in milk composition as affected by subclinical mastitis in goats. Journal of Dairy Science 2004, 87:1719-1726.

33. Laevens $H$, Deluyker $H$, Schukken $Y H$, De Meulemeester L, Vandermeersch $R$, De Muelenaere E, De Kruif A: Influence of parity and stage of lactation on the somatic cell count in bacteriologically negative dairy cows. Journal of Dairy Science 1997, 80:3219-3226.

34. Wilson DJ, Gonzalez RN, Das HH: Bovine mastitis pathogens in New York and Pennsylvania: Prevalence and effects on somatic cell count and milk production. Journal of Dairy Science 1997, 80:2592-2598.

35. Timms LL, Schultz LH: Dynamics and significance of coagulase-negative staphylococcal intramammary infections. Journal of Dairy Science 1987, 70:2648-2657.

36. Borm AA, Fox LK, Leslie KE, Hogan JS, Andrew SM, Moyes KM, Oliver SP, Schukken YH, Hancock DD, Gaskins TT, Owens WE, Norman C: Effects of prepartum intramammary antibiotic therapy on udder health, milk production, and reproductive performance in dairy heifers. Journal of Dairy Science 2006, 89:2090-2098.

37. Oliver SP, Gillespie BE, Ivey SJ, Lewis MJ, Johnson DL, Lamar KC, Moorehead H, Dowlen HH, Chester ST, Hallberg JW: Influence of prepartum pirlimycin hydrochloride or penicillin-novobiocin therapy on mastitis in heifers during early lactation. Journal of Dairy Science 2004, 87:1727-1731.

38. Burriel AR: Adhesion of coagulase-positive and coagulase-negative staphylococci to live ovine mammary epithelial cells. Small Ruminant Research 1999, 3:193-196.

39. Baselga R, Albizu I, De La Cruz M, Del Cacho E, Barberan M, Amorena B: Phase variation of slime production in Staphylococcus aureus implications in colonization and virulence. Infection and Immunity 1993, 61:4857-4862.

40. Osteras O, Aursjo J, Gjul GG, Jorstad A: Effect of dry-cow therapy on subclinical mastitis - an evaluation of long-acting and short-acting intramammaria. Journal of Veterinary Medicine B 1994, 41:529-540.

41. Weller J, Ezra E: Genetic analysis of the Israeli Holstein dairy cattle population for production and nonproduction traits with a multitrait animal model. Journal of Dairy Science 2004, 87:1519-1527.

doi:10.1186/1746-6148-7-3

Cite this article as: Leitner et al: An evaluation of casein hydrolyzate in combination with antibiotic for bacterial cure and subsequent increase in milk yield in dairy cows. BMC Veterinary Research 2011 7:3.

\section{Submit your next manuscript to BioMed Central and take full advantage of:}

- Convenient online submission

- Thorough peer review

- No space constraints or color figure charges

- Immediate publication on acceptance

- Inclusion in PubMed, CAS, Scopus and Google Scholar

- Research which is freely available for redistribution

Submit your manuscript at www.biomedcentral.com/submit 